\title{
Smoking Pattern, Reasons, Effects and Other Correlates of Smoking in Yenagoa Council Area of Bayelsa State
}

\author{
Owonaro A Peter ${ }^{1}$, Eniojukan F Joshua ${ }^{1}$ and Owonaro AE Daughter ${ }^{2}$ \\ ${ }^{1}$ Public Health Pharmacy Unit, Department of Clinical Pharmacy and Pharmacy Practice, Faculty of Pharmacy, Niger Delta University, Wilberforce \\ Island, Bayelsa State, Nigeria
}

${ }^{2}$ Skypat Pharmacy limited Yenagoa, Nigeria

Submission: February 08, 2017; Published: February 15, 2017

*Corresponding author: Owonaro A. Peter, Public Health Pharmacy Unit, Department of Clinical Pharmacy and Pharmacy Practice, Faculty of Pharmacy, Niger Delta University, Wilberforce Island, Bayelsa State, Nigeria, Email: daimondshoulder@yahoo.com

\begin{abstract}
Cigarette smoking induced deaths may likely increase from 5 million in 2010 to 10 million in a decade. In the $20^{\text {th }}$ century about 100 million deaths from tobacco was reported. If the current trends of smoking persist, tobacco will kill about 1 billion people this century, mostly in low- and middle-income countries. This study was set out to evaluate perceived causes, reasons of smoking, pattern of smoking and factors that influenced smoking. About 1,182 respondents agreed to participate after they were made to understand the full details of the study. The questionnaire captured demographic data, reasons for smoking, pattern of smoking and factors that influenced smoking.

$77.2 \%$ of respondents were male; within the age of 18 - 30 years; $2.5 \%$ of respondents had tertiary education; with an annual income of $501,000-1,000000 ; 57.8 \%$ were from Ijaw and $73.7 \%$ were Christians. $53.4 \%$ reported that they smoked to relieve stress; $57.5 \%$ to feel relaxed; $36.9 \%$ sometimes to increase sexual performance; $47.7 \%$ sometimes smoked to increase work output; $33.2 \%$ sometime smoked to be awake/ alert; $52.1 \%$ often smoked to enjoy with friends. $72 \%$ reported coughing; $64.3 \%$ reported chest pain; $33.6 \%$ experienced difficulties in sleeping; $27 \%$ had headache; $16.7 \%$ reported vomiting; $22.6 \%$ had hyperexcitement; $17.6 \%$ had hand shaking; $44.2 \%$ had general body pains; $42.7 \%$ had running nose and $33.2 \%$ reported sleepiness due to smoking. $41.2 \%$ of respondents reported that they smoked $6-10$ sticks of cigarette at a sitting; 55.3\% smoked 6-10 sticks a day within 15-30minutes interval. Benson and Hedges was the most favorite brand; $48.9 \%$ sometimes smoked in the company of friends. Gender; marital status; annual income and age group were not correlated with smoking prevalence. There is urgent need for antismoking campaign in the council area in conjunction with appropriate stakeholders.
\end{abstract}

Keywords: Cigarette smoking; Pattern; Yenagoa Bayelsa State

\section{Introduction}

Cigarette smoking is now a public health problem. The effects of smoking are known to smokers, still the rate at which people smoke increases on daily basis. Reason for the increased rate of smoking and addiction is said to be due to influence by friends or community member. Some studies have shown that young ones just start smoking by tasting it and get addicted and turn to regular smokers [1,2]. Cigarette contains about 700 chemicals in it. Studies have shown that about 250 out of the 700 chemicals are harmful. These include cyanide, carbon monoxide, ammonia and hydrogen. About 69 of the harmful chemicals are causative agents of cancer. They are Benzene, Beryllium, Butadiene and Cadmium Formaldehyde and Toluene etc $[1,3]$.

The United State Surgeon General in 2014 reported that cigarette smoking is estimated to cause about 480,000 deaths each year in the United States. Smoking induced deaths may likely increase from 5 million in 2010 and more than 10 million in a decade. In the $20^{\text {th }}$ century about 100 million deaths from tobacco was reported. If the current trends of smoking persist, tobacco will kill about 1 billion people this century, mostly in low- and middle-income countries [4]. This figure of the mortality burden of smoking may be an underestimate, because it considers deaths only from the 21 diseases $[5,6]$.

At age 14 to 18 years, which are the youths, they are mostly affected with smoking habit and become addicted for the rest of their life. This age is where the youths make choices for their life style and prepare for their future. This is the age where the inspiration is at the maximum, stress, attention disorder, psychological pressures and conflicts from parents play vital 
role in impacting the individual life styles [1,7]. In this study we intend to evaluate the perceived causes, reasons of smoking/ pattern of smoking and factors that influenced smoking.

\section{Method}

\section{Study population}

This study was carried out in Yenagoa council Area of Bayelsa State, South-South region of Nigeria with a population 266,008 at the 2006 census [8].

\section{Study Design and Sample}

A total of 1,300 questionnaires were given, but only 1, 182 respondents agreed to participate after they were made to understand the full details of the study. The sample size was calculated using the formula for evaluating the sample size population [9]. The questionnaire captured demographic data, reasons for smoking/ pattern of smoking and factors that influenced smoking.

\section{Data Analysis}

SPSS version 20 was utilized for data analysis. A t-test was also conducted using one way ANOVA.

\section{Results}

\section{Demography}

About 1,300 questionnaires were given; 1,182 were retrieved ( $90.9 \%$ response rate). A total of $77.2 \%$ of respondents were male; married (43.4\%); mostly within the age (39.2\%) of $18-30$ years. $62.5 \%$ of respondents had tertiary education; $49.7 \%$ were civil servants; with an annual income (43.5\%) of 501,000-1, $000000.71 .3 \%$ of the respondents lived in the urban city; I jaws were $57.8 \%$ and $73.7 \%$ were Christians (Table 1).

Table 1: Bio-socio-characteristics of respondents.

\begin{tabular}{|c|c|c|}
\hline Variable & Frequency & Percent \\
\hline \multicolumn{3}{|c|}{$\mathrm{N}=1182$} \\
\hline \multicolumn{3}{|c|}{ Sex } \\
\hline Male & 912 & 77.2 \\
\hline Female & 270 & 22.8 \\
\hline \multicolumn{3}{|c|}{ Marital status } \\
\hline Single & 476 & 40.3 \\
\hline Married & 513 & 43.4 \\
\hline Widowed & 193 & 16.3 \\
\hline \multicolumn{3}{|c|}{ Age group } \\
\hline $18-30$ & 463 & 39.2 \\
\hline $31-45$ & 317 & 26.8 \\
\hline $46-60$ & 283 & 23.9 \\
\hline 61 and above & 119 & 10.1 \\
\hline \multicolumn{3}{|c|}{ Education } \\
\hline Primary & 97 & 8.2 \\
\hline
\end{tabular}

\begin{tabular}{|c|c|c|}
\hline Secondary & 289 & 24.5 \\
\hline Tertiary & 739 & 62.5 \\
\hline Others & 57 & 4.8 \\
\hline \multicolumn{3}{|c|}{ Occupation } \\
\hline Civil servants* & 587 & 49.7 \\
\hline Military & 142 & 12.0 \\
\hline Students & 149 & 12.6 \\
\hline Unemployed/retired & 268 & 22.7 \\
\hline Others** & 36 & 3.0 \\
\hline \multicolumn{3}{|c|}{ Annual income (\#) } \\
\hline $50,000-100,000$ & 128 & 10.8 \\
\hline $101,000-500,000$ & 145 & 12.3 \\
\hline $501,000-1,000000$ & 514 & 43.5 \\
\hline $1,000000-<2,000000$ & 194 & 16.4 \\
\hline 2,000000 and above & 93 & 7.9 \\
\hline No response & 108 & 9.1 \\
\hline \multicolumn{3}{|c|}{ Place of residence } \\
\hline Urban & 843 & 71.3 \\
\hline Rural & 104 & 8.8 \\
\hline Semi-urban & 235 & 19.9 \\
\hline \multicolumn{3}{|c|}{ Religion } \\
\hline Christianity & 871 & 73.7 \\
\hline Islam & 207 & 17.5 \\
\hline Traditional & 58 & 4.9 \\
\hline Others & 46 & 3.9 \\
\hline \multicolumn{3}{|c|}{ Tribe } \\
\hline Ijaw & 683 & 57.8 \\
\hline Nembe & 200 & 16.9 \\
\hline Ogbia & 134 & 11.3 \\
\hline Igbo & 30 & 2.5 \\
\hline Others ${ }^{* * *}$ & 135 & 11.4 \\
\hline
\end{tabular}

a. including lecturers and school teachers

b. including farmers, artisans, drivers traders/business owners and contractors

c. including Urhobo, Isoko, Itsekiri and Yoruba

\section{Reasons for Smoking}

A total of $53.4 \%$ respondents reported that they smoked often to relieve stress; $57.5 \%$ to feel relaxed; $36.9 \%$ sometimes to increase sexual performance; $47.7 \%$ sometimes smoked to increase work output; $33.2 \%$ sometime smoked to be awake/ alert; $52.1 \%$ often smoked to enjoy with friends; $46.5 \%$ sometimes smoked to be social; $45.4 \%$ often smoked due to alcohol influence; $48.8 \%$ sometimes smoked to cool off; $41.4 \%$ and $48.7 \%$ often smoked when drinking and drink when smoking respectively. 


\section{Orthopedics and Rheumatology Open Access Journal}

\section{Pattern of Smoking}

A total of $48.9 \%$ respondents sometimes smoked in the company of friends while $16.3 \%$ sometimes smoked in the company of family/relatives and $33.3 \%$ sometimes smoked in the company of work mates (Table 2).

Table 2: Frequency-related reasons for smoking and pattern of smoking reported by smokers.

\begin{tabular}{|c|c|c|c|}
\hline \multicolumn{4}{|c|}{ Frequency (percent) } \\
\hline & Always & Sometimes & Never \\
\hline To relieve stress & $504(53.4)$ & $359(38.1)$ & $80(8.5)$ \\
\hline To feel relaxed & $542(57.5)$ & $333(35.3)$ & $68(7.2)$ \\
\hline $\begin{array}{l}\text { To increases sexual } \\
\text { performance }\end{array}$ & $302(32.0)$ & $348(36.9)$ & $274(29.1)$ \\
\hline To increase work output & 195 (20.7) & $450(47.7)$ & $298(31.6)$ \\
\hline To stay awake/alert & $202(21.4)$ & $313(33.2)$ & $428(45.4)$ \\
\hline $\begin{array}{l}\text { To enjoy with my } \\
\text { friends }\end{array}$ & $491(52.1)$ & 403 (42.7) & $49(5.2)$ \\
\hline In order to be sociable & $365(38.7)$ & $438(46.5)$ & $139(14.7)$ \\
\hline $\begin{array}{l}\text { Influenced by alcohol } \\
\text { drinking }\end{array}$ & $428(45.4)$ & $359(38.1)$ & $156(16.5)$ \\
\hline To cool off & $348(36.9)$ & $460(48.8)$ & $135(14.3)$ \\
\hline Smoke when drinking & $390(41.4)$ & $342(36.3)$ & $210(22.3)$ \\
\hline Drink when smoking & 459 (48.7) & $385(40.8)$ & $99(10.5)$ \\
\hline $\begin{array}{l}\text { In the company of } \\
\text { friends when smoking }\end{array}$ & $312(33.1)$ & $461(48.9)$ & $170(18.0)$ \\
\hline $\begin{array}{l}\text { In the company of } \\
\text { family/relatives when } \\
\text { smoking }\end{array}$ & $107(11.3)$ & $154(16.3)$ & $683(72.4)$ \\
\hline $\begin{array}{l}\text { In the company of work } \\
\text { mates when smoking }\end{array}$ & $209(22.2)$ & $314(33.3)$ & $420(44.5)$ \\
\hline
\end{tabular}

\section{Number of Sticks smoked and Frequency of Smoking}

Regarding number of sticks smokes at a sitting, 36.3\% of respondents smoked 1-5 sticks, 41.2\% smoked 6-10 sticks, while,55.3\% smoked the same quantity in $15-30$ minutes. $84.9 \%$ smoking in every 15-30 minutes. Benson and Hedges (39.3\%) as the most favorite brand and $66.2 \%$ reported that their favorite brand was always available and $66.4 \%$ will not smoke any other brand except their favorite. $63.2 \%$ took kola nut, if their favorite brand is not available. $42.7 \%$ reported that they have knowledge of what they are smoking. $87.6 \%$ and $65.4 \%$ smoked at home and parties respectively. $91.5 \%$ reported that they are aware smokers are liable to die young (Table 3 ).
Table 3: Number of Cigarette sticks smoked.

\begin{tabular}{|c|c|c|c|}
\hline & & Frequency & Percent \\
\hline \multirow[t]{4}{*}{$\begin{array}{c}\text { Number of cigarette sticks } \\
\text { smoked at a sitting }\end{array}$} & $1-5$ & 342 & 36.3 \\
\hline & $6-10$ & 389 & 41.2 \\
\hline & $11-15$ & 155 & 16.5 \\
\hline & $>15$ & 57 & 6.0 \\
\hline $\begin{array}{l}\text { Number of cigarette sticks } \\
\text { smoked per day }\end{array}$ & $1-5$ & 273 & 28.9 \\
\hline \multirow[t]{2}{*}{. } & $6-10$ & 521 & 55.3 \\
\hline & $>2$ packets & 149 & 15.8 \\
\hline \multirow[t]{2}{*}{ Frequency of smoking } & $\begin{array}{l}\text { A stick/15- } \\
\text { 30mins. }\end{array}$ & 801 & 84.9 \\
\hline & $\begin{array}{l}\text { A stick/ } \\
\text { half-1hr. }\end{array}$ & 142 & 15.1 \\
\hline \multirow[t]{4}{*}{ Favourite brand } & St. Moris & 268 & 28.4 \\
\hline & $\begin{array}{l}\text { Benson and } \\
\text { Hedges }\end{array}$ & 371 & 39.3 \\
\hline & Horis & 167 & 17.7 \\
\hline & Others & 137 & 14.6 \\
\hline \multirow[t]{3}{*}{ Availability of favourite brand } & Always & 624 & 66.2 \\
\hline & Sometimes & 259 & 27.5 \\
\hline & Never & 59 & 6.3 \\
\hline \multirow[t]{3}{*}{$\begin{array}{l}\text { When favourite brand is } \\
\text { unavailable }\end{array}$} & $\begin{array}{l}\text { Smoke any } \\
\text { brand }\end{array}$ & 28 & 3.0 \\
\hline & $\begin{array}{l}\text { Will not } \\
\text { smoke }\end{array}$ & 626 & 66.4 \\
\hline & $\begin{array}{l}\text { Take } \\
\text { alcohol }\end{array}$ & 289 & 30.6 \\
\hline \multirow[t]{7}{*}{ Other drugs used } & $\begin{array}{l}\text { Indian } \\
\text { hemp }\end{array}$ & 223 & 23.6 \\
\hline & Cocaine & 25 & 2.7 \\
\hline & $\begin{array}{l}\text { Raw } \\
\text { tobacco }\end{array}$ & 444 & 47.1 \\
\hline & Snuff & 367 & 38.9 \\
\hline & Kola nut & 596 & 63.2 \\
\hline & Monkey tail & 234 & 24.8 \\
\hline & Others & 153 & 16.2 \\
\hline \multirow[t]{3}{*}{$\begin{array}{l}\text { Knowledge of content of } \\
\text { cigarette }\end{array}$} & Yes & 40396696 & 42.7 \\
\hline & No & 236 & 25.1 \\
\hline & Not sure & 304 & 32.2 \\
\hline \multirow[t]{4}{*}{ Smoking setting } & At home & 826 & 87.6 \\
\hline & $\begin{array}{l}\text { At parties/ } \\
\text { ceremonies }\end{array}$ & 617 & 65.4 \\
\hline & $\begin{array}{l}\text { At work } \\
\text { place }\end{array}$ & 84 & 8.9 \\
\hline & Anywhere & 116 & 12.3 \\
\hline \multirow[t]{2}{*}{$\begin{array}{c}\text { Awareness of the cliché } \\
\text { "smokers are liable to die } \\
\text { young"? }\end{array}$} & Aware & 863 & 91.5 \\
\hline & Not aware & 80 & 8.5 \\
\hline
\end{tabular}




\section{Barriers to cessation of Smoking}

A total of $62.1 \%$ of respondents reported that they were addicted to smoking. 78.9\% smoked because they did not believe that smokers are liable to die young. $89.8 \%$ of respondents that were smokers reported that they were ready to stop smoking. $63.3 \%$ reported that they found it difficult to stop smoking. $63.8 \%$ reported that they had attempted to stop smoking. $62.7 \%$ and $87.1 \%$ reported that they tried to stop smoking but failed because of pressure from friends and too much temptation in it (Table 4).

Table 4: Barriers to cessation of Smoking.

\begin{tabular}{|c|c|c|c|}
\hline $\begin{array}{l}\text { Reasons for still } \\
\text { smoking }\end{array}$ & Addicted & 586 & 62.1 \\
\hline & $\begin{array}{l}\text { Don't believe smokers } \\
\text { are liable to die young }\end{array}$ & 744 & 78.9 \\
\hline & $\begin{array}{l}\text { Pressure from peer } \\
\text { group }\end{array}$ & 345 & 36.6 \\
\hline \multirow[t]{2}{*}{$\begin{array}{l}\text { Would you like to stop } \\
\text { smoking? }\end{array}$} & Yes & 847 & 89.8 \\
\hline & No & 96 & 10.2 \\
\hline \multirow[t]{2}{*}{$\begin{array}{l}\text { Do you find it difficult to } \\
\text { stop smoking? }\end{array}$} & Yes & 597 & 63.3 \\
\hline & No & 346 & 36.7 \\
\hline \multirow[t]{2}{*}{$\begin{array}{l}\text { Have you ever attempted } \\
\text { to stop smoking? }\end{array}$} & Yes & 602 & 63.8 \\
\hline & No & 341 & 36.2 \\
\hline \multirow{4}{*}{$\begin{array}{l}\text { How many times } \\
\text { have you tried to stop } \\
\text { smoking? }\end{array}$} & Once & 139 & 14.7 \\
\hline & Twice & 172 & 18.2 \\
\hline & Thrice & 232 & 24.6 \\
\hline & More than thrice & 401 & 42.5 \\
\hline \multirow[t]{3}{*}{$\begin{array}{l}\text { Why did the attempts to } \\
\text { stop smoking fail? }\end{array}$} & Pressure from friends & 591 & 62.7 \\
\hline & Too much temptation & 821 & 87.1 \\
\hline & Pressure from family & 69 & 7.3 \\
\hline
\end{tabular}

\section{Reported Effect of Smoking}

Regarding effects induced by smoking $72 \%$ reported coughing; $64.3 \%$ reported chest pain; $33.6 \%$ experienced difficulties in sleeping; $27 \%$ had headache; $16.7 \%$ reported vomiting; $22.6 \%$ had hyperexcitement; $17.6 \%$ had hand shaking; $44.2 \%$ with general body pains $42.7 \%$ had running nose and $33.2 \%$ reported sleepiness (Figure 1).

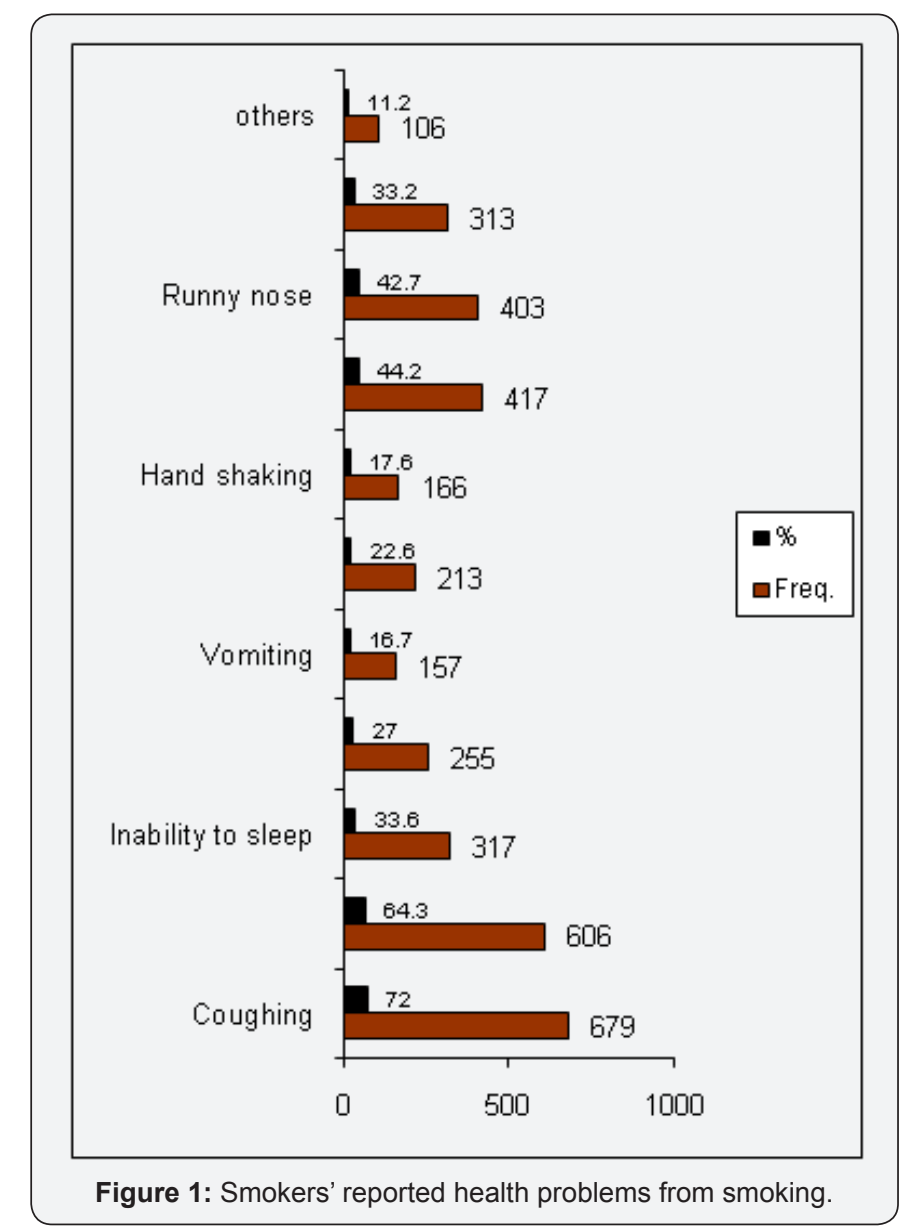

\section{Influence of Friends/Relative on Smoking}

$38.7 \%$ and $46.2 \%$ of respondents respectively were highly and moderately influenced into smoking via friends while $22.3 \%$ and $14.7 \%$ of respondents respectively were highly and moderately influenced into smoking by relatives (Figure 2).

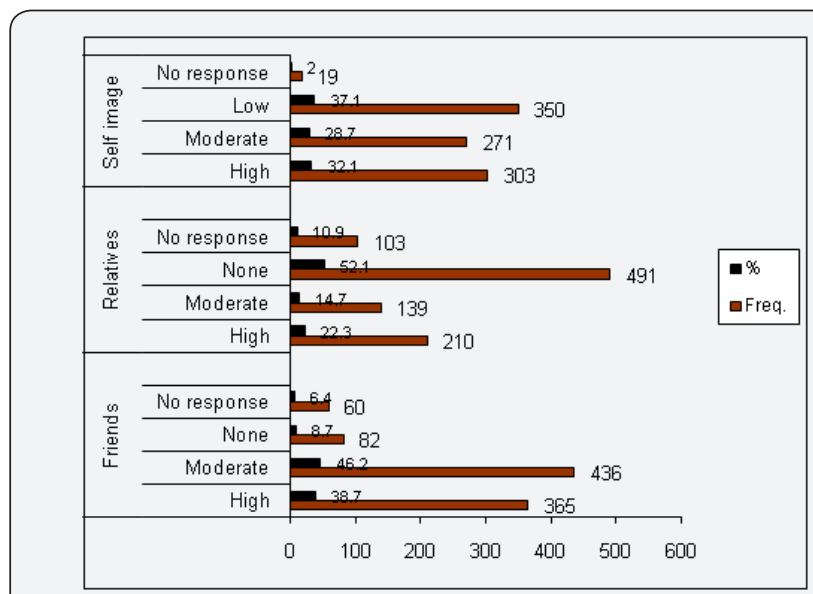

Figure 2: Level of Influence of friends and relatives on smoking habits and self image rating reported by smokers.

\section{Demography correlation with Smoking Prevalence}

Gender, marital status, annual income and age group were not correlated with smoking prevalence (Table 5). 


\section{Orthopedics and Rheumatology Open Access Journal}

Table 5: Chi-square demographic correlations with smoking prevalence.

\begin{tabular}{|c|c|c|c|c|c|}
\hline Variable & & Yes & No & Total & Statistics ( $\mathrm{P}$ value $<0.05$ is significant) \\
\hline \multirow[t]{2}{*}{ Gender } & Male & $808(88.6)$ & $104(11.4)$ & $912(100.0)$ & \multirow{2}{*}{$\mathrm{X}^{2}=0.488, \mathrm{df}=1 ; \mathrm{p}=0.274$} \\
\hline & Female & $235(87.0)$ & $35(13.0)$ & $270(100.0)$ & \\
\hline Total & & $1043(88.2)$ & $139(11.8)$ & $1182(100.0)$ & \\
\hline \multirow[t]{3}{*}{ Marital status } & Single & $424(89.1)$ & $52(10.9)$ & $476(100.0)$ & \multirow{3}{*}{$X^{2}=0.638, d f=2 ; p=0.727$} \\
\hline & Married & $451(87.9)$ & $62(12.1)$ & $513(100.0)$ & \\
\hline & Widow(er) & $168(87.0)$ & $25(13.0)$ & $193(100.0)$ & \\
\hline Total & & $1043(88.2)$ & $139(11.8)$ & $1182(100.0)$ & \multirow{5}{*}{$\mathrm{X}^{2}=2.717, \mathrm{df}=3 ; \mathrm{p}=0.437$} \\
\hline \multirow[t]{4}{*}{ Education } & Primary & $85(87.6)$ & $12(12.4)$ & $97(100.0)$ & \\
\hline & Secondary & $260(90.0)$ & $29(10.0)$ & $289(100.0)$ & \\
\hline & Tertiary & $651(88.1)$ & $88(11.9)$ & $739(100.0)$ & \\
\hline & Others & $47(82.5)$ & $10(17.5)$ & $57(100.0)$ & \\
\hline Total & & $1043(88.2)$ & $139(11.8)$ & $1182(100.0)$ & \\
\hline \multirow[t]{5}{*}{$\begin{array}{c}\text { Annual } \\
\text { income(\#) }\end{array}$} & $50-100,000$ & $11(89.8)$ & $13(10.2)$ & $128(100.0)$ & \multirow{5}{*}{$\mathrm{X}^{2}=7.523, \mathrm{df}=4 ; \mathrm{p}=0.111$} \\
\hline & $101-500,000$ & $130(89.7)$ & $15(10.3)$ & $145(100.0)$ & \\
\hline & $501-1,000000$ & $453(88.1)$ & $61(11.9)$ & $514(100.0)$ & \\
\hline & $1-2,000000$ & $177(91.2)$ & $17(8.8)$ & $194(100.0)$ & \\
\hline & $>2,000000$ & $75(80.6)$ & $18(19.4)$ & $93(100.0)$ & \\
\hline Total & & $950(88.5)$ & $124(11.5)$ & $1074(100.0)$ & \\
\hline \multirow[t]{4}{*}{ Age group(yrs.) } & $18-30$ & $412(89.0)$ & $51(11.0)$ & $463(100.0)$ & \\
\hline & $31-45$ & 278 (87.7) & $39(12.3)$ & $317(100.0)$ & \multirow{3}{*}{$X^{2}=0.666, d f=3 ; p=0.881$} \\
\hline & $46-60$ & $250(88.3)$ & 33 (11.7) & $283(100.0)$ & \\
\hline & 61and above & $103(86.6)$ & $16(13.4)$ & $119(100.0)$ & \\
\hline Total & & $1043(88.2)$ & $129(11.8)$ & $1182(100.0)$ & \\
\hline
\end{tabular}

\section{Discussion}

\section{Demography}

The study revealed that more male within the age group of 18-30 years participated. The respondents were more of the literates, working and majority earned 501,000-1, 000000 annually. They were mostly from lzon and were Christians. This is not surprising since Yenagoa council area is where the state capital of Bayelsa is located and it is entirely dominated by the lzon people and of the Christian faith [10].

\section{Reasons for Smoking}

Regarding reasons for smoking, various reasons were given by respondents for smoking always such as to relieve stress, relax, enjoy with friends and alcohol influence. This is similar to other studies $[4,11,12]$. Whereas, some smokers smoked sometimes to increase sexual performance, increase work output, to be alert/awake, to be social and to cool off. In reduction of stress; this rather causes craving for smoking, but is not linked with increase in smoking habit. This has further pointed out that smoking does not reduce stress rather increase the threshold of existing stress or initiate stress to the user. Hence, smokers were more stressed than non-smokers [12]. For increased sexual performance, respondents misinterpreted its effect as sex booster, rather smoking decreases sex. Studies have shown that smoking cessation enhances sexual performance. In the same vein other studies have reported no significant difference between smokers and non- smokers in connection to sexual performance $[13,14]$.

Regarding increase of work output, other studies have shown that smoking decreases physical activity, which contradicts claims of current smokers in this survey [14]. Smoking resulting to being awake or alert; this may be linked to the euphoric effect inherited from cigarette smoking. Some of the respondents sometimes smoked to enjoy with friends. This may be centred on the youths. Reasons may be just to be social with friends and to be active in their daily activities. However, the perceived reasons 
may be untrue rather it is the euphoric effect that gives them that feeling which is likely to be temporary without a reload of the content.

\section{Pattern of Smoking}

Regarding pattern of smoking, close to half of the respondents smoked in the company of their friends; whereas, only few family/relatives smoked in the company of workmates. Similar reports have shown that friend's smoked mostly in the company of their friends than relatives $[15,16]$. This may be a pointer to the fact that older adults always caution and are against youth smoking. The resultant effect is that youths concealed their smoking status to their family; especially parent and guardians. Whereas, friends and workmates have a lot of common character and attitude they share together $[17,18]$.

\section{Number of Stick smoked and Frequency of Smoking}

Most of the respondents smoked 1-5 cigarettes at a sitting and they smoked every 15-30minutes interval. About half of respondents that were smokers reported that they smoked 6-10 sticks of cigarette at a sitting. While 55.3\% smoked 6-10 sticks a day within 15-30minutes interval. This is on a high side. However, other studies have reported 1-4 sticks a day [19]. Light smokers and heavy smokers (6-10 sticks) are still exposed to the negative effect of smoking [20]. A survey recorded that people who smoked up to four cigarettes a day were about 50 per cent more likely to die prematurely than non-smokers [21].

This is also similar with the report of Million Women survey stating that smoking more than 10 cigarettes a day is likely for the smokers to die prematurely, compared to a non-smoker [20]. Benson and Hedges was the most favorite brand and most of the respondents reported that it was always available. However, respondents addicted to it do not smoke when the favorite brand was not available. Most of respondents that are smokers also took kola nut. In the absence of their favorite brand, kola nut may be used as remedy to suppress the craving effect for cigarette smoking.

\section{Barriers to cessation of smoking}

Majority of the smokers were aware of content of what they smoked. However, the awareness did not deter them from smoking because they were addicted to it. Also majority of them did not believe that smokers are liable to die young which is contrary to other studies [22]. This might have encouraged their smoking habit. Almost all the smokers were willing to stop smoking; a few tried but failed. Their reasons were basically addiction and influence of peer pressure. This is similar to other studies [15,23].

\section{Reported Effect of Smoking}

Regarding effects induced by smoking, most of the respondents reported coughing. This might be due to weakening of the lungs from accumulation of toxins in the respiratory system [24]. Also more than half of the respondents reported chest pain, experience difficulties in sleeping, had headache; few of the respondents reported that they experienced vomiting, hyperexcitement, hand shaking, with general body pains, running nose and sleepiness. A study in Bayelsa state earlier also reported the aforementioned side effects due to smoking. Most of these side-effects initially presented are temporal in nature, but later results to deleterious chronic effects with high rate of morbidity and mortality known from cigarette smoking [25]. Tobacco smokers are often associated with several hazards that can eventually lead to reduction of the smokers' and secondhand smokers' life span.

\section{Friends/Relative influence on Smoking}

About half of smokers in Yenagoa council area reported that they were influenced by friends, This is in conformity with several studies [26-30]. This is not surprising, as most smokers are always associated with friends that also smoked. This is followed with some respondents indicating family relatives as a major factor that influenced their smoking habits. Respondents linked factors that influenced smoking as friends; implicating them as a major factor that influenced their smoking habits. This survey shows that family and relatives were a major factor that influenced their smoking habits. This is in conformity with other studies [30].

In Japan a study carried out have equally pointed out that smoking habit is linked with mothers' smoking history, school teachers that smoke and with very close friends that are smokers [30]. Beside this, parents that are smokers expose their children as second hand smokers that are equally prone to adverse health consequences, economic loss and the chances of such becoming smokers is inevitable.

\section{Demography correlation with Smoking Prevalence}

Gender; marital status; annual income and age group were not correlated with smoking prevalence.

\section{Conclusion}

The study revealed that more male within the age group of 18-30 years participated. Their annual income fell between $501,000-1,000000$. The respondents were mostly from I jaw and Christian worshippers. Respondents gave various reasons for smoking; most of them, reasons for smoking were to relieve them of stress, relax, enjoy with friends and alcohol influence.

About close to half of the respondents smoked in the company of their friends. Only $16.3 \%$ of respondents smoked in the company of their family/relatives and $33.3 \%$ smoked in the company of workmates. Half of the respondents smoked 6-10 sticks of cigarette at a sitting. 55.3\% smoked 6-10 sticks a day within 15-30 minutes interval. Benson and Hedges was the most favorite brand and was always available. Regarding effects induced by smoking, several effects were reported but coughing was the highest effect experienced by smokers. This was closely followed by chest pain, difficulties in sleeping, headache, 
vomiting, hyper excitement, hand shaking, general body pains, running nose and sleepiness. Friends were reported to be the highest influencers that initiate smoking. Gender; marital status; annual income and age group were not correlated with smoking prevalence.

\section{References}

1. Khurshid F, Urusa Ansari U (2012) Causes of Smoking Habit among the Teenagers. Interdisciplinary Journal of Current Research in Business 3(9): 848.

2. Balabanova D, Bobak M, McKee M (1998) Patterns of smoking in Bulgaria. Tob Control 7(4): 383-385.

3. Ng M, Freeman MK, Fleming TD, Robinson M, Dwyer-Lindgren L, et al. (2014) Smoking Prevalence and Cigarette Consumption in 187 Countries, 1980-2012. JAMA 311(2): 183-192.

4. US Surgeon General (2010) How Tobacco Smoke Causes Disease : The Biology and Behavioral Basis for Smoking-Attributable Disease.

5. Carter BD, Abnet CC, Feskanich D, Freedman ND, Hartge P, et al. (2015) Smoking and Mortality - Beyond Established Causes. N Engl J Med 372: 631-640.

6. Prabhat Jha, Richard Peto (2014) Global Effects of Smoking, of Quitting, and of Taxing Tobacco. N Engl J Med 370: 60-68.

7. Lugo A, Vecchia C, Boccia S, Murisic B, Gallus S (2013) Patterns of Smoking Prevalence among the Elderly in Europe. Int J Environ Res Public Health 10(9): 4418-4431.

8. Wikipedia 2009, Nigeria 2006 census.

9. Araoye MO (2003) Research methodology with statistics for health and social sciences. Nathadex Publishers Ilorin 117-118.

10. Wikipedia. Ijaw People.

11. Frobisher C, Winter DL, Lancashire ER, Reulen RC, Taylor AJ, et al. (2008) Extent of Smoking and Age at Initiation of Smoking Among Adult Survivors of Childhood Cancer in Britain. J Natl Cancer Inst 100(15): 1068-1081.

12. Owonaro AP and Eniojukan JF (2016) Smoking Prevalence and interacting factors in a Semi Urban Community in Niger Delta Region of Nigeria. International Journal of Preclinical \& Pharmaceutical Research 7(1): 1-10.

13. Pirie K, Peto R, Reeves GK, Green J, Beral V (2013) The 21st century hazards of smoking and benefits of stopping: a prospective study of one million women in the UK. Lancet 381(9861): 133-141.

14. Efroymsona D, Ahmedb S, Townsendc J, Alamb S, Dharb B (2010) Hungry for tobacco: an analysis of the economic impact of tobacco consumption on the poor in Bangladesh. Tob Control 10(3): 212-217.

15. Saari AJ, Kentala J, Mattila KJ (2014) The smoking habit of a close friend or family member-how deep is the impact? A cross-sectional study. BMJ Open 4(2): e003218.
16. Jarvie JA (2008) Smoke Exposure in Private Homes and Cars: An Ethical Analysis. Am J Public Health 98(12): 2140-2145.

17. Owonaro PA, Eniojukan JF (2015) The Prevalence and Contextual Correlates of Smoking in Opokuma Clan of Bayelsa State, Nigeria. IJAPBC 4(3).

18. Cronk NJ, Harris KJ, Harrar SW, Conway K, Catley D (2011) Analysis of smoking patterns and contexts among college student smokers. Subst Use Misuse 46(8): 1015-1022.

19. Bjartveit K, A Tverdal A (2005) Health consequences of smoking 1-4 cigarettes per day. Tob Control 14(5): 315-320.

20. Frobisher C, Winter DL, Lancashire ER, Reulen RC, Taylor AJ, et al. (2008) Extent of Smoking and Age at Initiation of Smoking Among Adult Survivors of Childhood Cancer in Britain. J Natl Cancer Inst 100(15): 1068-1081.

21. Onongha GI (2013) Influence of Cigarette Warning Label on Smoking Behaviour among Education Students of Osun State University, Osogbo. Nigeria. J of Education and Practice 4(5).

22. McGee CE, TrigwelI J, Fairclough SJ, Murphy RC, Lorna Porcellato L, et al. (2015) Influence of family and friend smoking on intentions to smoke and smoking-related attitudes and refusal self-efficacy among 9-10 year old children from deprived neighbourhoods: a crosssectional study. BMC Public Health 15: 225.

23. Dania MG, Ozoh B, Bandele EO (2015) Smoking habits, awareness of risks, and attitude towards tobacco control policies among medical students in Lagos, Nigeria. Ann Afr Med 14(1): 1-7.

24. Emily Banks, Grace Joshy, Marianne F Weber, Bette Liu, Robert Grenfell, et al. (2015) Tobacco smoking and all-cause mortality in a large Australian cohort study: findings from a mature epidemic with current low smoking prevalence. BMC Medicine 13(38): 15-281.

25. França LR, Dautzenberg B, Falissard B, Reynaud M (2009) Are social norms associated with smoking in French university students? A survey report on smoking correlates. Subst Abuse Treat Prev Policy 4(4): 1747.

26. Naito T, Miyaki K, Naito M, Yoneda M, SuzukiN, et al. (2009) Parental Smoking and Smoking Status of Japanese Dental Hygiene Students: A Pilot Survey at a Dental Hygiene School in Japan. Int. J. Environ. Res. Public Health 6(1): 321-328

27. Adeyeye 00 (2011) Cigarette smoking habits among senior secondary school students in Lagos, south west Nigeria. Int J Biol Med Res 2(4): 1047-1050.

28. Ukwayi JK, Eja OF, Unwanede CC (2012) Peer Pressure and Tobacco Smoking among Undergraduate Students of the University of Calabar, Cross River State. Higher Education Studies 2(3): 92-101.

29. Nargiso JE, Becker SJ, Wolff JC, Uhl KM, Simon V, et al. (2012) Psychological, Peer, and Family Influence on Smoking Among an Adolescent Psychiatric Sample. J Subst Abuse Treat 42(3): 310-318.

30. Surgeon General (2010) How Tobacco Smoke Causes Disease : The Biology and Behavioral Basis for Smoking-Attributable Disease. 
(C) C. Commons Attribution 4.0 License
- Quality Editorial service

- Swift Peer Review

- Reprints availability

- E-prints Service

- Manuscript Podcast for convenient understanding

- Global attainment for your research

- Manuscript accessibility in different formats

( Pdf, E-pub, Full Text, Audio)

- Unceasing customer service

Track the below URL for one-step submission https://juniperpublishers.com/online-submission.php 